\title{
FAKTOR-FAKTOR YANG MEMPENGARUHI KELENGKAPAN PENGUNGKAPAN DALAM LAPORAN TAHUNAN PADAPERUSAHAAN PERDAGANGAN PERIODE 2012-2014 DI BURSA EFEK INDONESIA
}

\author{
Yulia Istia Ningsih \\ Fakultas Ekonomi, Jurusn D3 Akuntansi \\ Sekolah Tinggi Ilmu Ekonomi Graha Karya Muara Bulian \\ E-mail:yuliastiegk@gmail.com
}

\begin{abstract}
This research aims to know the factors that affect the completeness of the disclosure in the annual report on trading company registered in BEI 2012-2014 year. The selection of the sample using a purposive sampling. Based on the criteria of the 45 companies that become the population, retrieved 15 companies that are being sampled in this study. The independent variable in this study is the liquidity, leverage, net profit margin, the company's size and age of the company. While the dependent variable is represented by the level of disclosure of information in the annual report with the awarding of the score over the disclosure items that are listed in the annual report. The results of this research show that partially during the period of 2012-2014 for the size of the company's positive effect towards completeness of disclosure in the annual report. As for liquidity, leverage, net profit margin, and the age of the company does not affect the completeness of the disclosure in the annual report. Simultaneously influence among variables showed a non towards completeness of disclosure in the annual report.
\end{abstract}

Keywords: Disclosure annual report, liquidity, Leverage, Net Profit Margin, the company's Size, age of the company

\section{PENDAHULUAN}

Profesi akuntansi sebagai penyedia informasi bisnis tidak dapat melepaskan diri dari perkembangan perekonomian ini.Semakin besar suatu usaha bisnis, semakin dirasakan perlunya informasi akuntansi akuntansi, baik untuk pertanggung jawaban maupun untuk dasar pengambilan keputusan ekonomi.Dalam hubungannya dengan pengujian informasi keuangan untuk pihak luar, profesi akuntansi perlu mengatur cara-cara pengujian informasi keuangan suatu badan usaha dan member jasa audit untuk menentukan kewajaran laporan keuangan yang disusun oleh manajemen.

Suatu laporan keuangan sangat bermanfaat bagi sejumlah besar pengguna apabila informasi yang disajikan dalam laporan keuangan tersebut dapat dipahami, relevan, andal, dan dapat diperbandingkan. Namun demikian, perlu disadari bahwa laporan keuangan tidak menyediakan semua informasi yang mungkin dibutuhkan pengguna dalam pengambilan keputusan ekonomi. Secara umum, laporan keuangan menggambarkan pengaruh dari kejadian masa lalu, dan tidak diwajibkan untuk menyediakan informasi non keuangan. (Adisetiawan dan Surono, 2016)

Agar laporan keuangan yang sudah diperiksa oleh akuntan publik dapat menjadi dasar yang berguna bagi pengambilan keputusan, salah satu cara yang dapat ditempuh adalah dengan membuat kriteria perlunya disclosure (pengungkapan) tertentu yang dapat mencakup semua perusahaan publik (Irawan, 
2006). Pengungkapan dalam laporan keuangan dapat dikelompokkan menjadi dua bagian yaitu pengungkapan wajib (Mandatory Disclosure) dan pengungkapan sukarela (Voluntary Disclosure).Pengungkapan wajib merupakan pengungkapan minimum yang disyaratkan oleh standar akuntansi yang berlaku (peraturan mengenai pengungkapan laporan keuangan yang dikeluarkan oleh pemerintah melalui keputusan ketua BAPEPAM No.SE02/PM/2002).Sedangkan pengungkapan sukarela merupakan pilihan bebas manajemen perusahaan untuk memberikan informasi akuntansi dan informasi lainnya yang dipandang relevan untuk keputusan oleh para pemakai laporan keuangan tersebut.Menurut peraturan mengenai keuangan yang ada di Indonesia hal semacam ini dimungkinkan.

Penelitian tentang kelengkapan pengungkapan dalam laporan tahunan dan faktor-faktor yang mempengaruhinya merupakan hal penting yang dilakukan. Dimana akan memberikan gambaran tentang sifat perbedaan kelengkapan pengungkapan antar perusahaan dan faktor-faktor yang mempengaruhinya, serta dapat memberikan petunjuk tentang kondisi perusahaan pada masa pelaporan. Dalam pencapaian efisiensi dan sebagai sarana akuntabilitas publik, pengungkapan laporan keuangan menjadi faktor yang signifikan.Pengungkapan laporan keuangan dapat dilakukan dalam bentuk penjelasan mengenai kebijakan akuntansi yang ditempuh, kontijensi, metode persediaan, dan jumlah saham yang beredar dan ukuran alternatif, misalnya pos-pos yang dicatat dalam historical cost.

Laporan tahunan pada dasarnya merupakan sumber informasi bagi investor sebagai salah satu dasar pertimbangan dalam pengambilan keputusan investasi pasar modal dan juga sebagai sarana pertanggungjawaban manajemen atas sumber daya yang dipercayakan kepadanya.Tujuan pelaporan keuangan adalah untuk memberikan informasi guna pengambilan keputusan, informasi diungkapkan pada dasarnya diarahkan kepada para pemegang saham, para investor lainnya dan kreditur.Tetapi para karyawan, instansi pemerintah dan masyarakat luas juga merupakan penerima laporan tahunan dan bentuk pengungkapan lainnya. Dalam mekanisme pasar modal, pengungkapan badan usaha merupakan suatu cara untuk menyalurkan pertanggungjawaban perusahaan kepada para investor untuk memudahkan alokasi sumber daya. Hal ini menunjukkan bahwa laporan tahunan merupakan media yang penting untuk menyampaikan corporate disclosure (pengungkapan pada laporan tahunan) oleh manajemen suatu badan usaha dan merupakan sumber informasi yang penting dalam pengambilan keputusan investasi oleh para investor. (Adisetiawan, 2012)

Selanjutnya Adisetiawan (2012) mengungkapkan bahwa akuntansi sebagai alat pertanggung jawaban mempunyai fungsi sebagai alat kendali terhadap aktivitas suatu unit usaha. Tanggung jawab manajemen tidak hanya terbatas atas pengelolaan dana ke dalam perusahaan kepada investor dan kreditur, tetapi juga meliputi dampak yang ditimbulkan oleh perusahaan terhadap lingkungan alam dan sosialnya. Keterkaitan yang terjadi antara perusahaan dengan lingkungan alam dan sosialnya, serta manfaat sosial (social benefits) dan biaya sosial (social cost) yang ditimbulkannya merupakan sisi aspek sosial pertanggung jawaban manajemen.

Penelitian ini merupakan replikasi dari penelitian Laraswita dan Indrayani (2009), perbedaan penelitian ini dengan penelitian sebelumnya yaitu pada variabel, perusahaan dan periode. Alasan peneliti memilih judul ini karena di dalam penelitian Novalita Laraswati dan Emmy Indrayani (2009) menyarankan agar dalam penelitian selanjutnya dapat menambahkan variabel yang dapat 
mempengaruhi kelengkapan pengungkapan laporan tahunan dan mengganti objek penelitiannya supaya hasil penelitian tidak terbatas hanya pada sektor properti dan real estate.

Selain itu, perusahaan perdagangan juga memiliki peranan yang sangat penting bagi perekonomian Indonesia khususnya msyarakat Indonesia dan perusahaan perdagangan menempatkan diri sebagai industri kedua tertinggi dalam penyerapan tenaga kerja di Indonesia. Variabel yang digunakan dalam penelitian ini adalah likuiditas, leverage, net profit margin, ukuran perusahaan, dan umur perusahaan sebagai variabel bebas dan kelengkapan pengungkapan laporan keuangan sebagai variabel terikat. Perusahaan perdagangan yang terdaftar di BEI periode 2012-2014 yakni sebanyak 47 perusahaan dan berdasarkan uraian kriteria penentuan sampel, maka diperoleh sampel sebanyak 15 perusahaan.

Hasil penelitian sebelumnya diperoleh ada beberapa variabel yang sama namun dengan hasil yang signifikan dan tidak signifikan. Penelitian yang sama diteliti oleh Bambang Irawan (2006) dengan hasil penelitian menyatakan bahwa ukuran perusahaan dan umur perusahaan berpengaruh terhadap kelengkapan pengungkapan laporan keuangan. Variabel lainnya seperti leverage, likuiditas, dan net profit margin tidak berpengaruh terhadap kelengkapan pengungkapan laporan keuangan. Nina Sofiani (2010) dengan hasil penelitian menyatakan bahwa variabel leverage, net profit margin, mempengaruhi kelengkapan pengungkapan, sedangkan variabel likuiditas dan ukuran perusahaan tidak berpengaruh terhadap kelengkapan pengungkapan dalam laporan keuangan.

Almilia dan Retrinasari (2007) dengan hasil penelitian bahwa variabel likuiditas dan ukuran perusahaan berpengaruh terhadap kelengkapan pengungkapan laporan keuangan, namun variabel leverage dan net profit margin tidak berpengaruh terhadap kelengkapan pengungkapan laporan keuangan. Novalita Laraswita dan Emmy Indrayani (2009) menyatakan hasil penelitian bahwa variabel net profit margin berpengaruh terhadap tingkat kelengkapan pengungkapan laporan tahunan perusahaan, sedangkan variabel Debt to Equity Ratio dan ukuran perusahaan tidak memiliki pengaruh terhadap tingkat kelengkapan pengungkapan laporan tahunan perusahaan. Maka dari itu, motivasi dalam penelitian ini adalah untuk menguji konsistensi faktor-faktor yang mempengaruhi kelengkapan perngungkapan dalam laporan tahunan.

\section{Tinjauan Pustaka, Kerangka Pemikiran Dan Hipotesis}

\section{Pengungkapan Laporan Keuangan Pada Perusahaan Perdagangan di Indonesia}

Dalam penelitian ini, laporan keuangan tahunan perusahaan perdagangan berpedoman atas Surat Edaran Ketua Pengawas Pasar Modal Nomor : SE02/PM/2002 Tanggal : 27 Desember 2002.

Adapun ikhtisar dari pengungkapan yang harus dipenuhi adalah sebagai berikut:

a. Gambaran Umum Perusahaan

Bagian ini berisi penjelasan tentang hal-hal umum yang penting untukdiungkapkan berkaitan dengan perusahaan yang bersangkutan, mencakup:

1) Pendirian Perusahaan

Penjelasan mengenai pendirian perusahaan beserta perubahan terhadapanggaran dasar, yang antara lain meliputi: 
a) Riwayat perusahaan,

b) Akta Pendirian dan perubahan anggaran dasar terakhir, pengesahan oleh Menteri Kehakiman atau pengumuman pada Lembaran Berita Negara.

c) Tempat kedudukan perusahaan dan tempat toko beroperasi.

2) Bidang usaha utama perusahaan sesuai dengan anggaran dasar perusahaan dan kegiatan usaha yang dijalankan.

3) Tanggal mulai beroperasinya perusahaan secara komersial. Apabila perusahaan melakukan ekspansi atau penciutan usaha secara signifikan pada periode laporan yang disajikan, harus disebutkan saat dimulainya operasi komersial dari ekspansi atau penciutan perusahaan dan kapasitas produksinya.

b. Penawaran Umum Efek Perusahaan

Penjelasan penawaran umum efek perusahaan yang meliputi tanggal efektifpenawaran umum perdana, kebijakan/tindakan perusahaan yang dapatmempengaruhi efek yang diterbitkan (corporate action) sejak penawaranumum perdana sampai dengan periode pelaporan terakhir, jenis dan jumlahefek yang ditawarkan pada saat penawaran terakhir, dan tempat pencatatanefek perusahaan.

c. Karyawan, Direksi dan Dewan Komisaris, yang harus diungkapkan antara lain:

1) Nama anggota direksi dan dewan komisaris,

2) Jumlah karyawan pada akhir periode atau rata-rata jumlah karyawan selama periode yang bersangkutan.

d. Ikhtisar kebijakan akuntansi

Hal-hal yang harus diungkapkan dalam ikhtisar kebijakan akuntansi antara lain: dasar pengukuran laporan keuangan dan kebijakan akuntansi tentang yang diterapkan terhadap peristiwa dan transaksi penting. Dalam dasar pengukuran dan penyusunan laporan keuangan, hal-hal yang harus diungkapkan yaitu: dasar pengukuran laporan keuangan yaitu berdasarkan nilai historis, asumsi dasar dalam penyusunan laporan keuangan, mata uang pelaporan yang dipergunakan dan alasannya, alasan perubahan periode pelaporan (jika ada). Dalam kebijakan akuntansi tertentu yang diterapkan terhadap peristiwa dan transaksi penting, hal-hal yang harus diungkapkan yaitu: kebijakan terhadap kas dan setara kas, piutang, persediaan, investasi efek, investasi selain efek, aktiva tetap, sewa guna usaha, aktiva tidak berwujud, aktiva lain-lain, penurunan nilai aktiva, restrukturisasi hutang bermasalah, pengakuan pendapatan, biaya pinjaman, pajak penghasilan, program pensiun, laba/rugi per lembar saham, transaksi dan saldo dalam mata uang asing, instrumen derivatif dan segmen usaha.

e. Pengungkapan atas pos-pos laporan keuangan dan pengungkapan lainnya.

Bagian ini menjelaskan hal-hal yang penting untuk diungkapkan pada tiaptiap pos, yang dapat mempengaruhi pembaca dalam pengambilan keputusan, yang disusun dengan memperhatikan urutan penyajian Neraca, Laporan Laba Rugi, Laporan Perubahan Ekuitas dan Laporan Arus Kas, serta informasi tambahan. 


\section{Luas Pengungkapan}

Keluasan pengungkapan adalah salah satu bentuk kualitas pengungkapan.Menurut Naim dan Rakhman (2000), kualitas tampak sebagai atribut-atribut yang penting dari suatu informasi akuntansi.Meskipun kualitas akuntansi masih memiliki makna ganda (ambigous), banyak kualitas pengungkapan dapat diukur dan digunakan untuk menilai manfaat potensial dari isi suatu laporan tahunan.

Menurut Harahap (2007) ada tiga konsep mengenai luas pengungkapan laporan keuangan.Konsep itu adalah adequate, fair, dan full disclosure.

1. Adequate disclosure (pengungkapan cukup)

Konsep yang sering digunakan adalah pengungkapan yang cukup, yaitu pengungkapan minimum yang disyaratkan oleh peraturan yang berlaku, dimana angka-angka yang disajikan dapat diinterpretasikan dengan benar oleh investor.

2. Fair disclosure (pengungkapan wajar)

Pengungkapan yang wajar secara tidak langsung merupakan tujuan atis agar memberikan perlakuan yang sama kepada semua pemakai laporan keuangan menyediakan informasi yang layak terhadap pembaca potensial.

3. Full disclosure (pengungkapan penuh)

Pengungkapan penuh menyangkut kelengkapan penyajian informasi yang diungkapkan secara relevan.Pengungkapan penuh memiliki kesan penyajian informasi secara melimpah sehingga beberapa pihak menganggapnya tidak baik.Bagi beberapa pihak pengungkapan secara penuh diartikan sebagai penyajian informasi yang berlebihan dan karena itu tidak bisa disebut layak.Terlalu banyak informasi yang signifikan membuat laporan sulit ditafsirkan.Dampak negatif lainnya adalah kompetisi yang dinamis dalam pasar produk.Tersebarnya informasi penting yang berkaitan dengan strategi bisnis dan rencana perusahaan merugikan posisi kompetitif perusahaan sendiri.

Menurut Chairi dan Ghozali (2007), menyatakan ada dua jenis pengungkapan dalam hubungannya dengan persyaratan yang ditetapkan standar, yaitu:

a. Pengungkapan wajib (mandatory disclosure)

Pengungkapan wajib adalah pengungkapan minimum yang disyaratkan oleh standar akuntansi yang berlaku.Di Indonesia peraturan mengenai pengungkapan informasi dalam laporan tahunan dikeluarkan oleh Ketua BAPEPAM melalui keputusan nomor 17/PM/2002 atau VIII.G.7.Dalam praktik yang paling lazim digunakan adalah pengungkapan yang cukup (Adequate Disclosure).

b. Pengungkapan sukarela (voluntary disclosure)

Pengungkapan sukarela merupakan pengungkapan butir-butir yang dilakukan secara sukarela oleh perusahaan tanpa diharuskan oleh standar atau peraturan yang berlaku.Dalam pengungkapan sukarela menajemen bebas untuk member informasi akuntansi maupun informasi lainnya di luar standar pengungkapan yang sudah ditetapkan. Pengungkapan sukarela berisi taksiran laba yang akan dibagi oleh manajemen, penyajian kepada public, pengungkapan relasi investor, website, internet, press release, konferensi pers, informasi sukarela dalam laporan tahunan, juga semua informasi kebijakan perusahaan yang dapat dipakai untuk berbagai tujuan. 
Investor sering kali mencari sumber informasi selain laporan tahunan untuk memenuhi kebutuhannya.Semakin banyak informasi yang diungkapkan maka laporan keuangan semakininformatif dan penyajian informasi yang semakin tinggi. Oleh karena itu manajemen perlu mempertimbangkan cost and benefit dalam menyajikan pengungkapan di dalam laporan keuangan atau laporan tahunan.

\section{Pengungkapan dalam Laporan Keuangan}

Menurut pandangan tradisional, pengungkapan yang disajikan harus memenuhi kriteria relevan sesuai dengan tujuan kualitatif pelaporan keuangan. Hal ini menimbulkan kesulitan karena suatu informasi relevan untuk suatu tujuan mungkin tidak relevan untuk tujuan yang lain, sedangkan elemen-elemen pengungkapan mencakup:

a. Laporan laba-rugi

b. Laporan perubahan posisi keuangan

c. Laporan sumber dan penggunaan dana

d. Catatan atas laporan keuangan

e. Laporan audit berikut:

Jadi secara garis besar penempatan pengungkapan mengikuti pedoman

1. Laporan keuangan

Terdiri dari tiga laporan keuangan yaitu: neraca, laporan laba-rugi dan laporan perubahan posisi keuangan. Pengungkapan dalam laporan keuangan bisa dalam bentuk laporan laba-rugi, laporan perubahan posisi keuangan termasuk rincian dan table-tabel untuk menjelaskan angka yang terdapat dalam laporan keuangan yang disajikan secara kompetitif dalam periode yang lalu.

2. Catatan kaki

Ini merupakan bagian yang tidak terpisahkan dari laporan keuangan, sehingga dalam catatan kaki sering disajikan catatan-catatan yang berhubungan dengan item-item neraca dan laporan laba-rugi.

3. Data statistik

Data-data ini disusun dan diolah dari angka-angka yang terdapat dalam laporan keuangan dan sering kali disajikan secara terpisah di dalam laporan tambahan.

4. Laporan auditor

Laporan ini merupakan media yang paling sesuai untuk mengungkap penyimpangan dan akibat penyimpangan penerapan prinsip akuntansi dan akibatnyam perbedaan pendapat antara auditor dan manajemen perusahaan yang diaudit.

Pengungkapan informatif yang memadai yang disajikan oleh suatu perusahaan tidak sama dengan perusahaan lain. Memadai berarti tidak berlebihan namun juga tidak kurang sehingga tidak menyesatkan orang yang membacanya.Dalam pernyataan Standar Akuntansi Keuangan (PSAK) No. 1 disebutkan bahwa manajeman wajib mengungkapkan kebijakan akuntansi yang diterapkan dalam manajeman laporan keuangannya. Para pemakai laporan keuangan membutuhkan keterangan kebijakan akuntansi pilihan sebagai bagian informasi yang dibutuhkan untuk membuat penilaian, keputusan keuangan dan keperluan lain. Mereka tidak dapat membuat penilaian handal jika laporan 
keuangan tidak mengungkapkan dengan jelas kebijakan akuntansi pilihan yang penting dalam penyusunan laporan keuangan.

\section{Faktor-faktor yang Mempengaruhi Kelengkapan Pengungkapan Laporan Keuangan}

Pengungkapan laporan keuangan merupakan suatu hal yang harus dilakukan oleh perusahaan dalam menyusun laporan keuangan, pengungkapan ini melibatkan keseluruhan proses pelaporan. Tetapi terdapat beberapa metode yang berbeda-beda untuk pengungkapan ini, pemilihan metode yang terbaik dari pengungkapan ini pada setiap kasus tergantung pada sifat informasi yang bersangkutan dan kepentingan relatifnya.

Metode yang biasa dari pengungkapan ini dapat diklasifikasikan sebagai beriku: bentuk dan susunan laporan yang formal, terminologi dan penyajian yang terinci, informasi selipan, catatan kaki, ikhtisar tambahan dan skedul, komentar sertifikat auditor, dan pernyataan direktur utama atau ketua dewan komisaris. Selain itu terdapat faktor-faktor yang dapat mempengaruhi kelengkapan pengungkapan laporan keuangan perusahaan yang menjadi acuan dalam penelitian ini adalah likuiditas, leverage, net profit margin, ukuran perusahaan dan umur perusahaan.

a. Pengaruh Rasio Likuiditas terhadap Kelengkapan Pengungkapan Laporan Tahunan.

Tingkat likuiditas dapat dipandang dari dua sisi.Kesehatan suatu perusahaan yang dicerminkan dengan tingginya rasio likuiditas (diukur dengan current ratio) diharapkan berhubungan dengan luasnya tingkat pengungkapan. Hal ini didasarkan dari adanya pengharapan bahwa secara finansial perusahaan yang kuat akan lebih mengungkapkan informasi daripada perusahaan yang lemah. Tetapi sebaliknya, jika likuiditas dipandang sebagai ukuran kinerja, perusahaan yang mempunyai rasio likuiditas rendah perlu memberikan informasi yang lebih rinci untuk menjelaskan lemahnya kinerja dibanding perusahaan yang mempunyai rasio likuiditas yang tinggi.

b. Pengaruh Rasio Leverage terhadap Kelengkapan Pengungkapan Laporan Tahunan.

Leverage merupakan perbandingan antara utang dengan ekuitas pemegang saham. Perusahaan dengan leverage tinggi menanggung biaya pengawasan yang tinggi. Jika menyediakan informasi secara lebih komprehensif akan membutuhkan biaya lebih tinggi, maka perusahaan dengan leverage yang lebih tinggi akan menyediakan informasi secara lebih komprehensif.

c. Pengaruh Rasio Net Profit Margin terhadap Kelengkapan Pengungkapan Laporan Tahunan.

Rasio profitabilitas merupakan rasio yang mengukur kemampuan perusahaan dalam menghasilkan laba pada tingkat penjualan, asset, dan modal.Net profit margin atau disebut rasio profitabilitas, rentabilitas ekonomi dan profit margin yang tinggi akan mendorong para manajer untuk memberikan informasi yang lebih rinci, sebab mereka ingin meyakinkan investor terhadap profitabilitas perusahaan dan mendorong kompensasi terhadap manajemen. Jadi semakin tinggi net profit margin suatu perusahaan maka semakin tinggi indeks kelengkapan pengungkapannya.

d. Pengaruh Ukuran Perusahaan Terhadap Kelengkapan Pengungkapan Laporan Tahunan. 
Secara umum, perusahaan besar akan mengungkapkan informasi lebih banyak daripada perusahaan kecil. Size perusahan yang dinyatakan dengan market capitalized diharapkan berhubungan dengan luasnya tingkat tingkat pengungkapan. Perusahaan yang berukuran lebih besar cenderung memiliki publik demand akan informasi yang lebih tinggi dengan perusahaan yang berukuran kecil. Alasan lainnya adalah bahwa perusahaan besar mempunyai biaya produksi informasi yang lebih rendahyang berkaitan dengan pengungkapan mereka atau biaya competitive disadvantage yang lebih rendah pula.

e. Pengaruh Umur Perusahaan Terhadap Kelengkapan Pengungkapan Laporan Tahunan.

Umur Perusahaan diperkirakan memiliki hubungan positif dengan kualitas pengungkapan.Alasan yang mendasari adalah bahwa perusahaan yang berumur lebih tua memiliki pengalaman yang lebih banyak dalam mempublikasikan laporan. Perusahaan yang memiliki pengalaman lebih banyak akan lebih mengetahui kebutuhan kostituennya akan informasi tentang perusahaan.

\section{METODE}

\section{Populasi dan Sampel Penelitian}

Populasi dalam penelitian ini adalah perusahaan perdagangan yang terdaftar di Bursa Efek Indonesia pada tahun 2012-2014. Pemilihan sampel dilakukan dengan metode purposive sampling. Dalam penelitian ini kriteria yang ditetapkan adalah sebagai berikut:

1. Perusahaan perdagangan yang menerbitkan laporan keuangan dan catatan atas laporan keuangan tahun 2012-2014 secara berturut-turut.

2. Perusahaan yang mempunyai laporan keuangan yang berakhir 31 Desember.

3. Perusahaan yang memiliki laba positif.

4. Data perusahaan yang dibutuhkan tersedia.

Dari perusahaan perdagangan yang terdaftar di Bursa Efek Indonesia pada tahun 2012-2014 yaitu sebanyak 47 perusahaan dan berdasarkan uraian kriteria penentuan sampel di atas, maka diperoleh sampel yang berjumlah 15 perusahaan perdagangan.

\section{Data dan Metode Pengumpulan Data}

Data yang digunakan dalam penelitian ini merupakan data sekunder, yaitu data yang diperoleh peneliti secara tidak langsung melalui media perantara.Data sekunder umumnya berupa bukti, catatan atau laporan historis yang telah tersusun dalam arsip (data dokumenter) yang dipublikasikan dan laporan keuangan yang ada di www.idx.co.id. Data-data yang diperlukan untuk penelitian ini antara lain:

1. Jenis perusahaan yang termasuk dalam industri perdagangan yang terdaftar di BEI.

2. Indeks laporan keuangan masing-masing sampel yang diperoleh dari butir-butir kelengkapan laporan tahunan perusahaan diperoleh dari BAPEPAM No. SE02/PM/2002).

3. Data tentang rata-rata aktiva, rasio likuiditas, leverage, net profit margin, ukuran perusahaan dan umur perusahaan dapat diambil dari laporan keuangan perusahaan industri perdagangan di Bursa Efek Indonesia periode 2012-2014. 


\section{HASIL}

\section{Uji Asumsi Klasik}

Model regresi dapat digunakan untuk estimasi dengan signifikan dan representatif jika model regresi tersebut tidak menyimpang dari asumsi klasik regresi berupa: normalitas, multikolinearitas, heteroskedastisitas, dan autokorelasi.

Uji Normalitas

Tabel 1

Hasil Uji Statisitik Non Parametrik Kolmogorov-Smirnov Test One-Sample Kolmogorov-Smirnov Test

\begin{tabular}{|ll|l|l|l|l|l|l|}
\hline & & $\mathrm{Y}$ & $\mathrm{X} 1$ & $\mathrm{X} 2$ & $\mathrm{X} 3$ & $\mathrm{X} 4$ & $\mathrm{X} 5$ \\
\hline $\mathrm{N}$ & & 45 & 45 & 45 & 45 & 45 & 45 \\
Normal Parametersa & Mean & -.004620 & -.000489 & -.001400 & -.037634 & -.036643 & -.021920 \\
& Std. Deviation & .9740752 & .9772577 & .9776044 & .9484215 & .9282373 & .9538490 \\
Most Extreme Differences & Absolute & .153 & .312 & .167 & .276 & .089 & .172 \\
& Positive & .153 & .312 & .167 & .276 & .089 & .160 \\
& Negative & -.146 & -.205 & -.109 & -.116 & -.072 & -.172 \\
Kolmogorov-Smirnov Z & & 1.025 & 2.092 & 1.119 & 1.851 & .599 & 1.154 \\
Asymp. Sig. (2-tailed) & & .244 & .252 & .163 & .072 & .866 & .139 \\
\hline
\end{tabular}

Sumber : Output SPSS

Berdasarkan hasil output spss 16.0, distribusi data dinyatakan normal karena signifikannya menunjukkan hasil diatas 5\%. Dengan demikian dapat disimpulkan bahwamasing-masing variabel bebas di dalam model regresi ini distribusi datanya normal.Dan berdasarkan Grafik P-Plot dapat dilihat bahwa data mengikuti garis diagonal sehingga dapat disimpulkan bahwa data berdistribusi normal.

\section{Gambar 1}

\section{Grafik P-Plot}

Normal P-P Plot of Regression Standardized Residual

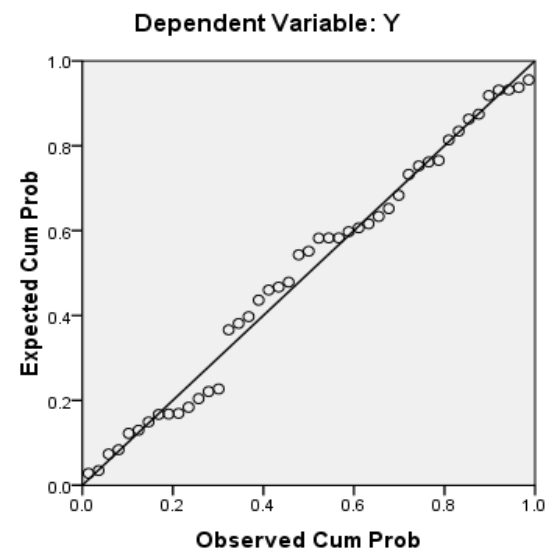




\section{Heterokesdastisitas}

\section{Gambar 2 \\ Grafik Scatterplot}

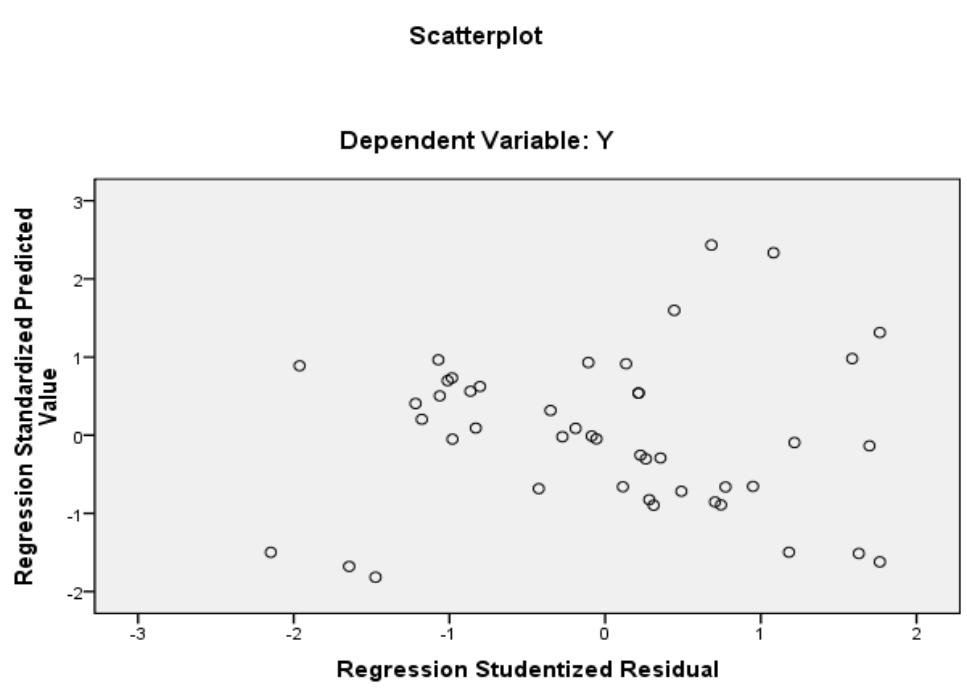

Selain menggunakan grafik scatterplot, uji heteroskedastisitas dalam penelitian ini juga menggunakan uji glejser, berikut adalah hasil uji heteroskedastisitas menggunakan uji glejser.

Tabel 2

Koefisien

\begin{tabular}{|ll|l|l|l|l|l|}
\hline \multirow{2}{*}{ Model } & \multicolumn{2}{|l|}{ Unstandardized Coefficients } & Standardized Coefficients & & \\
\cline { 2 - 5 } & $\mathrm{B}$ & Std. Error & Beta & $\mathrm{t}$ & Sig. \\
\hline 1 & (Constant) & .608 & .059 & & 10.387 & .000 \\
& X1 & .136 & .089 & .318 & 1.533 & .133 \\
X2 & .210 & .077 & .491 & 2.750 & .099 \\
X3 & -.085 & .072 & -.192 & -1.184 & .244 \\
X4 & -.037 & .073 & -.083 & -.516 & .609 \\
X5 & .119 & .082 & .270 & 1.441 & .157 \\
\hline
\end{tabular}

Sumber : Output SPSS

Berdasarkan tabel di atas, dapat dilihat jika nilai signifikansi dari variabel tersebut $>0.05$, hal ini menunjukkan bahwa variabel di atas diketahui tidak memiliki hubungan antara variabel bebas dengan nilai mutlak residual sehingga menunjukkan tidak adanya masalah heteroskesdasitas dalam model regresi.

\section{Uji Multikolinearitas}

Uji multikolinearitas pada penelitian menunjukkan hasil sebagai berikut: 
Tabel 3

Nilai Tolerance dan VIF

\begin{tabular}{|ll|l|l|}
\hline \multicolumn{3}{|c|}{ Nilai Tolerance dan VIF } \\
\hline \multicolumn{2}{|l|}{ Model } & Collinearity Statistics \\
\cline { 2 - 4 } & (Constant) & & \\
& X1 & .463 & 2.159 \\
X2 & .624 & 1.602 \\
X3 & .757 & 1.321 \\
X4 & .771 & 1.297 \\
X5 & .565 & 1.770 \\
\hline
\end{tabular}

Sumber : Output SPSS

Berdasarkan tabel diatas terlihat bahwa tidak ada variabel bebas yang memiliki nilai VIF yang besar dari 10. Hal ini berarti tidak ada korelasi antar variabel bebas, sehingga dapat disimpulkan bahwa data bebas dari masalah multikolinearitas.

\section{Uji Autokorelasi}

Tabel 4

Hasil Uji Autokorelasi

Sumber : Output SPSS

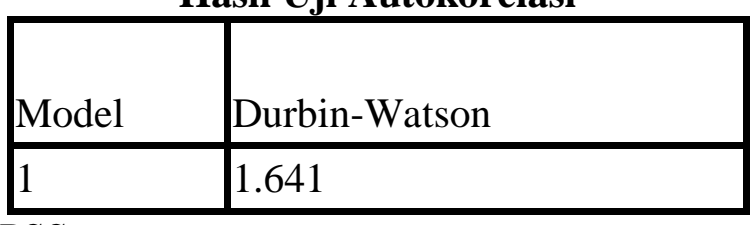

Model regresi yang diperoleh dalam penelitian ini memiliki nilai statistik Durbin-Watson $\mathrm{d}=1.641$, hal ini menunjukkan bahwa tidak adanya autokorelasi karena berdasarkan kriteria Durbin-Watson nilai 1.641 berada pada range antara 1.55-2.64, maka hal ini berarti tidak ada masalah autokorelasi data dalam penelitian ini. Pembuatan persamaan regresi berganda dengan menggunakan output SPSS dapat dilakukan dengan menginterpretasikan angka-angka yang termuat dalam Tabel 2, hubungan antara variabel independen dengan variabel dependen dapat dirumuskan dalam persamaan sebagai berikut:

$\mathrm{Y}=0.016+0.044 \mathrm{X}_{1}-0.131 \mathrm{X}_{2}-0.113 \mathrm{X}_{3}+0.692 \mathrm{X}_{4}-0.019 \mathrm{X}_{5}$

Persamaan regresi diatas mempunyai makna sebagai berikut :

1. Koefisien regresi untuk variabel $X_{1}$ yaitu variabel likuiditas sebesar 0.044. Nilai koefisien tersebut menunjukkan bahwa jika likuiditas naik $1 \%$ maka indeks pengungkapan laporan tahunan akan naik sebesar 0.044

2. Koefisien regresi untuk variabel $\mathrm{X}_{2}$ yaitu variabel leverage sebesar 0.131.Nilai koefisien tersebut menunjukkan bahwa jika leverage naik $1 \%$ maka indeks pengungkapan laporan tahunan akanturun sebesar -0.131 .

3. Koefisien regresi untuk variabel $\mathrm{X}_{3}$ yaitu variabel Net Profit Margin sebesar 0.113 Nilai koefisien tersebut menunjukkan bahwa jika Net ProfitMargin naik $1 \%$ maka indeks pengungkapan laporan tahunan akanturun sebesar 0.113 . 
4. Koefisien regresi untuk variabel $\mathrm{X}_{4}$ yaitu variabel Ukuran Perusahaan sebesar 0.692. Nilai koefisien tersebut menunjukkan bahwa jika Ukuran Perusahaan naik $1 \%$ maka indeks pengungkapan laporan tahunan akannaik sebesar 0.692 .

5. Koefisien regresi untuk variabel $\mathrm{X}_{5}$ yaitu variabel umur perusahaan sebesar 0.019. Nilai koefisien tersebut menunjukkan bahwa jika umur perusahaan naik $1 \%$ maka indeks pengungkapan laporan tahunan akanturun sebesar 0.019 .

\section{Uji Hipotesis}

Uji asumsi klasik yang dilakukan terhadap persamaan regresi menyimpulkan bahwa persamaan tersebut layak digunakan dalam model peramaan matematis.Pengujian hipotesis dilakukan dengan menggunakan uji koefisien determinasi, uji statistik t, dan uji statistik F. Uji koefisien determinasi yaitu mengukur seberapa jauh kemampuan model dalam menerangkan variasi variabel dependen.Uji signifikansi parameter individual (uji statistik t) digunakan untuk menguji hubungan masing-masing variabel independen terhadap variabel dependen.Uji signifikansi simultan (uji statistik F), menunjukkan apakah semua variabel independen yang dimasukkan dalam model mempunyai pengaruh secara bersama-sama terhadap variabel dependen.

\section{Koefisien Determinasi}

Hasil uji koefisien determinasi penelitian dapat dilihat di tabel berikut ini:

Tabel 6 Model Summary

\begin{tabular}{|l|l|l|l|l|}
\hline Model & $\mathrm{R}$ & R Square & Adjusted R Square & Std. Error of the Estimate \\
\hline 1 & $.643^{\mathrm{a}}$ & .414 & .339 & .7919655 \\
\hline
\end{tabular}

Sumber: output SPSS

Pada Tabel 6 diatas dapat dilihat bahwa nilai adjusted $\mathrm{R}$ Square sebesar 0.339. Hal ini berarti 34 persen variasi kelengkapan pengungkapan laporan tahunan dapat dijelaskan oleh Likuiditas, Leverage ,Net Profit Margin, Ukuran Perusahaan dan Umur perusahaan. Sisanya 66 persen dijelaskan oleh faktor lain yang tidak disertakan dalam variabel penelitian ini.

\section{Uji Parsial}

Untuk variabel penelitian Likuiditas, dalam Tabel 2 diatas bahwa standardized coefficients variabel Likuiditassebesar 0.044 untuk hasil uji t-hitung sebesar 0.246. Nilai signifikansinya sebesar 0.807 dan angka ini lebih dari 0.05, ini menunjukkan bahwa tidak signifikansi dari variabel Likuiditas,terhadap Kelengkapan pengungkapan laporan tahunan perusahaan.Kesimpulannya Likuiditas tidak berpengaruh terhadap Kelengkapan pengungkapan laporan tahunan perusahaan.

Untuk variabel penelitian Leverage pada tabel diatas menunjukkan bahwa Leverage mempunyai t-hitung sebesar -0.847 dengan standardized coefficients variabel sebesar -0.131. Karena nilai signifikan variabel Leverage adalah 0.402 , 
dimana nilai ini $>0.05$ yang berarti variabel Leverage tidak berpengaruh terhadap Kelengkapan pengungkapan laporan tahunan perusahaan.

Untuk variabel penelitian Net Profit Margin pada tabel diatas menunjukkan bahwa Net Profit Margin mempunyai t-hitung sebesar -0.782 dengan standardized coefficients variabel sebesar -0.110. Karena nilai signifikan variabel Net Profit Margin adalah 0.439, dimana nilai ini > 0.05 yang berarti variabel Net Profit Margin tidak berpengaruh terhadap Kelengkapan pengungkapan laporan tahunan perusahaan.

Untuk variabel penelitian Ukuran Perusahaan pada tabel diatas menunjukkan bahwa Ukuran Perusahaan mempunyai t-hitung sebesar 4.724dengan standardized coefficients variabel sebesar 0.659. Karena nilai signifikan variabel Ukuran Perusahaan adalah 0.000, dimana nilai ini $<0.05$ yang berarti variabel Ukuran Perusahaan berpengaruh terhadap Kelengkapan pengungkapan laporan tahunan perusahaan.

Untuk variabel penelitian Umur Perusahaan pada tabel diatas menunjukkan bahwa Umur Perusahaan mempunyai t-hitung sebesar -0.115 dengan standardized coefficients variabel sebesar -0.019. Karena nilai signifikan variabel Umur Perusahaan adalah 0.909 , dimana nilai ini $>0.05$ yang berarti variabelUmur Perusahaan tidak berpengaruh terhadap Kelengkapan pengungkapan laporan tahunan perusahaan.

\section{Uji Simultan}

Untuk menguji signifikansi pengaruh Likuiditas, Leverage, Net Profit Margin, Ukuran Perusahaan dan Umur perusahaan terhadap Kelengkapan pengungkapan laporan tahunan perusahaan secara simultan digunakan alat uji statistik "F" yang dapat dilihat dari hasil output program SPSS versi 16.0 pada Tabel 7 sebagai berikut:

Tabel 7

Anova

\begin{tabular}{|ll|l|l|l|l|l|}
\hline \multicolumn{2}{|l|}{ Model } & Sum of Squares & df & Mean Square & F & Sig. \\
\hline 1 & Regression & 17.287 & 5 & 3.457 & 5.512 & $.001^{\mathrm{a}}$ \\
& Residual & 24.461 & 39 & .627 & & \\
& Total & 41.748 & 44 & & & \\
\hline
\end{tabular}

Sumber : Output Spss

Dengan demikian dapat dibandingkan bahwa nilai $p$ value $(0.001 \mathrm{a})<0.05$ maka H0 ditolak dan $\mathrm{Ha}$ diterima, berarti secara bersama-sama variabel Likuiditas, Leverage, Net Profit Margin,Ukuran Perusahaan dan Umur perusahaanberpengaruh terhadap Kelengkapan pengungkapan laporan tahunan perusahaan.

\section{SIMPULAN} berikut:

Berdasarkan hasil penelitian, maka dapat ditarik kesimpulan sebagai

1. Likuiditas, Leverage, Net Profit Margin dan Umur Perusahaan secara parsial tidak berpengaruh terhadap kelengkapan pengungkapan dalam laporan tahunan perusahaan perdagangan periode 2012-2014yang terdaftar di Bursa 
Efek Indonesia, sedangkan variabel ukuran perusahaan secara parsial berpengaruh terhadap terhadap kelengkapan pengungkapan dalam laporan tahunan perusahaan perdagangan periode 2012-2014 yang terdaftar di Bursa Efek Indonesia.

2. Likuiditas, Leverage, Net Profit Margin, Ukuran Perusahaan, dan Umur Perusahaan secara simultan berpengaruh terhadap terhadap kelengkapan pengungkapan dalam laporan tahunan perusahaan perdagangan periode 20122014 yang terdaftar di Bursa Efek Indonesia.

3. Besaran pengaruh Rasio Likuiditas, Rasio Leverage, Net Profit Margin, Ukuran Perusahaan, dan Umur Perusahaan terhadap kelengkapan pengungkapan dalam laporan tahunan perusahaan perdagangan yaitu sebesar $33.9 \%$, hal ini dilihat dari nilai Adjusted R Square sebesar 0.339. Hal ini berarti 34\% variasi kelengkapan pengungkapan dalam laporan tahunan dapat dijelaskan oleh Rasio Likuiditas, Rasio Leverage, Net Profit Margin, Ukuran Perusahaan, dan Umur Perusahaan. Sisanya 66\% dijelaskan oleh faktor.

\section{DAFTAR PUSTAKA}

Adisetiawan, R., and Surono, Yunan., 2016, Earnings Management and Accounting Information Value: Impact and Relevance, Business, Management and Economics Research, 2(10): 170-179

Adisetiawan, R., 2013, Kebijakan Akuntansi terhadap Manajemen Laba, Akuntabilitas: Jurnal Ilmiah Akuntansi, 12(2): 298-311

Almilia, Luciana Spica dan Ikka Retrinasari. 2007. "Analisis Pengaruh Karakteristik Perusahaan Terhadap Kelengkapan Pengungkapkan Dalam Laporan Tahunan Perusahaan Manufkatur yang Terdaftar di BEJ", Simposium Nasional Akuntansi.

Chairis, Anis dan Imam Ghazali. 2007. Teori Akuntansi. Edisi ke Tiga. Universitas Diponegoro.

Irawan, Bambang. 2006. Faktor- Faktor yang Mempengaruhi kelengkapan Pengungkapan Laporan Keuangan Pada Perusahaan Manufkatur yang Terdaftar di Bursa Efek Indonesia.Fakultas Ekonomi Universitas Islam Indonesia.Yogyakarta.

Ikatan Akuntansi Indonesia. 2009. Standar Akuntansi Keuangan. Jakarta :Salemba Empat.

Indriantoro, Nur., 2002. Metodologi Penelitian Bisnis Untuk Akuntansi dan Manajemen.Yogyakarta :BPFE.

Harahap, Sofyan Syafri., 2007. Teori Akuntansi. Edisi Revisi. Jakarta: PT. Raja Grafindo Persada.

Kasmir. 2010. Analisis Laporan Keuangan. Jakarta : Rajagrafindo Persada.

Laraswati, Novalita dan Emmy Indrayani.2010. Pengaruh Karakterisitk Perusahaan Terhadap Kelengkapan pengungkapan Dalam Laporan Tahunan Sektor Properti dan Real Estate Yang Terdaftar di BEI. Jurnal Akuntansi.

Marwata.2001. Hubungan Antara Karakteristik Perusahaan dan Kualitas Ungkapan Sukarela Dalam Laporan Tahunan Perusahaan Publik di Indonesia.Makalah Dipresentasikan dalam Simposium Nasional Akuntansi IV.2001.

Munawir. 2010. Analisis Laporan Keuangan Edisi Empat. Yogyakarta: Liberty.

Naim, Ainun dan Fuad Rachman. 2000. Analisis Hubungan Antara Kelengkapan Pengungkapan Laporan Keuangan Dengan Struktur Modal dan Tipe 
Kepemilikan Perusahaan. Jurnal Ekonomi dan Bisnis Indonesia Vol. 15 N0.1.pp.70-82.

Sofiana, Nina., 2010. Analisis pengaruh Karakterisitk Perusahaan Terhadap Kelengkapan Pengungkapan Dalam Laporan Tahunan Perusahaan Manufaktur Yang Terdaftar di BEI. Fakultas Ekonomi Universitas Muhammadiyah Surakarta.

Sugiyono. 2007. Metode Penelitian Bisnis. Bandung: Alfa.

Surat Edaran Ketua Pengawas Pasar Modal Nomor : SE-02/PM/2002 Tanggal : 27

Desember 2002. 